\title{
СЕМАНТИКА ЧАСУ, ПРОСТОРУ, МІСЦЯ Й ГЕРОЯ У ТВОРІ БІГУНИ ОЛЬГИ ТОКАРЧУК
}

\author{
Наталія Розінкевич \\ Фаховий коледж «Універсум» Київського університету імені Бориса Грінченка \\ Київ, Україна \\ ORCID:0000-0002-7292-1015
}

\section{THE SEMANTIC SOFTIME, SPACE, PLACE AND CHARACTER IN BIGUNY (RUNNERS) BY OLHA TOKARCHUK}

\begin{abstract}
The article analyzes the individual spatio-temporal model of life as a set of various realities of artistic reality, presented in the work Biguny (Runners) by modern Polish writer Olga Tokarchuk, Nobel Prize winner.

It is emphasized that Olga Tokarchuk considers the philosophy of traveling as a means of world knowledge through the prism of «going beyond».

It is found out that the characters while traveling model the world in some way: they fill it with personal meanings based on their world view; at the same time metaphysical and geographical spaces conceptually transform their image. Reality under goes transformations as well: authenticity is replaced by artificiality, and artificiality creates artificiality.

Olha Tokarchuk persuades the reader that the world is transformative, flexible, and created by imagination, and it looks like a coordinate system of various ideas. You can look at things from different perspectives, and in order to understand the world, you must first understand a man.
\end{abstract}

Key words: time, space, place, character

У творах сучасних авторів змінилося ставлення до мандрів: раніше подорож трактували “як полярну експедицію”, зараз - подорожжю можна вважати й поїздку в метро․ Як наслідок, вектори змін у творах спрямовують наукові дослідження на вивчення процесу психології подорожі i iï метафорики. Мандри переходять із зовнішнього у метафізичний, ірраціональний (сюрреалістичний) простір i, виходячи за межі, концептуально переінакшують образ героя.

У кожної мандрівки є відправна точка, відносно якої виникає відчуття близькості чи віддаленості. Під час руху відбувається вихід за межі звич-

1 О. Токарчук, Бігуни, пер. 3 пол. О. Т. Сливинського, Харків 2011, с. 96. 
них уявлень, за межі соціоцентрованості й егоцентрованості й у процесі осягнення нового простору формується онтологічне уявлення про інакший світ та набувається екзистенційний досвід. Мандри - це метафора виходу з власного життя, що робить можливим перехід від одного способу буття до іншого, що стає ціллю, чи має протяжність у декілька років, або ж усвідомлюються, що “насправді ніякого руху немає" та "ніхто не перебуває в конкретному часі та місці"2.

Герої-мандрівники під час руху певним чином моделюють світ: картину світу наповнюють особистими смислами, залежно від власного світогляду, іноді - сакралізують, тому що часово-просторова модель буття в кожній людській свідомості індивідуальна, а "час і простір - лише суб'єктивне втілення, понятійно-смислове наповнення об'єктивних, спільних для людства мислесхем"з.

Від кінця XX століття продовжується тяглість у відтворенні поведінкових моделей мандрівників у літературі: фланера, туриста, гравця, блукальця, кочівника, тотального безпритульця, самітника, метафізичного бунтівника. Однак на початку XXI століття активно проявляються нові моделі таких героїв: дослідника, аналітика, репортера, журналіста, історика, етнографа, паломника, мандрівного філософа, медіатора, здійснювача мрій, організатора гри, спостерігача, переборювача постколоніального синдрому, співрозмовника, медіатора, рюкзачника, хічхайкера, бекпекера, флешпекера, глобтроттера, сталкера, культурно-освіченої людини тощо. Мадлена Шульгун, наприклад, виділяє складну модель мандрівного філософа з рисами пасіонарності й ідеологічності ${ }^{4}$.

У цій статті спробуємо розглянути хронотопні аспекти (функціонування елементів часового й просторового мислення) художньої дійсності твору Бігуни, в які занурені та які творять герої польської письменниці Ольги Токарчук.

Славомір Івасів довів, що у всій прозі авторки наявні “мотиви, пов'язані з подорожами та мобільністю у різних аспектах", а саме: подорож як сприйняття різної реальності, подорож слідами інших, позачасова, мобільна, непряма, розважальна, перевернута, туристична, подорож-“захоплення", подорож-ініціація та перетворення, подорож-проникнення, “міфічна" і соціальна тощо. “Токарчук часто тягнеться до подорожі, по-

Там само, с. 63, 390.

Р. Козлов, Хронотопіка Франкових драм: теорія, практика, інтерпретаичія, Кривий Ріг 2012 , с. 86.

4 М. Шульгун, Метажанр подорожі в контексті перехідного художнього мислення (кінець $X X-$ поч. $X X I$ cm.): дис. ... докт. філол. наук: 10.01.06; 10.01.05, Київ 2017, с. 282 284.

5 S. Iwasiów, ,, Celem mojej pielgrzymki jest zawsze inny pielgrzym ”: podróż w prozie Olgi Tokarczuk, „Fraza: poezja, proza, esej” 2013, p. 22, № 3 (81), c. 170. 
казуючи ії в різних вимірах - не без перебільшення можна сказати, що це проза подорожей, і практично в кожній книзі авторка виражає своє захоплення рухливістю світу, людей та предметів"б.

Роксоляна Свято твердить, що Бігуни Ольги Токарчук - це "роман у фрагментах", який складається 3 десятків "самостійних сюжетних ліній”, які, проте, виявляються “«опорною конструкцією» що утримує вкупі весь текст"

Анна Ларента робить висновок, що твір має лабіринтну структуру i “Токарчук пропонує читачеві (...) роздуми над філософськими та психологічними умовами людського стану, суттю якого $є$ рух"

Сюжетна дія твору розгортається на дуже широкому й різноманітному географічному фоні: Бельгія, Голландія, Стокгольм, Відень, Прага тощо. Однак найчастіше у ньому невизначений простір - “в якомусь місці"” і неозначений час.

Будь-який твір, в якому є мандри за межі іншої країни, функціонально націлений на порівняння "свого” і “чужого”. Однак, слід зазначити, дихотомічні концепти зображень у мовній когнітивній свідомості (“свій” - “чужий”, “свій” - “ворожий”, “наш” - “інший”) детермінуються в прозі XXI століття у парадигми: “наш” - “ваш”, “наш” - “іхній”, “тут” - “там”, "ми" - “вони". Утім, у творі Ольги Токарчук ці опозиції стерті, тому що відбувається “перетинання (...) культурних кодів"10, вихід за рамки звичного. Це і $€$ формою сучасного існування людини і ії процесом світопізнання.

Авторка, зазвичай, не називає точні назви автострад, летовищ, потягів, шосе, кораблів, рейсів автобусів, готелів тощо - тобто не зациклюється на деталях. Однак, акцентує увагу на тому, що вона за національністю полька, але не проводить паралелі між моделлю життя поляків у Польщі з “іншими” в "інших" країнах, не розглядає питань польської історії, відсутні й етнографічні деталі, що вказували б на національність авторки, але Ольга Токарчук зосереджує свою увагу на деталях, знаках, асоціаціях, деконструкціях, і не шукає якихось порівнянь “інших" із етнонаціональними особливостями поляків.

Анна Ларента звернула увагу, що “у творчості Токарчук співіснують географічний простір та міфічний простір" і всі топоси для героїв виконують функцію індивідуального сприйняття світу як лабіринту-коре-

Там само, с. 174.

Р. Свято, Бігуни: рецеензія, “Критика" 2013, № 5-6, с. 187-188.

$8 \quad$ A. Larenta, Labirynt jako przestrzeń mityczna w Biegunach Olgi Tokarczuk, "Białostockie Studia Literaturoznawcze", 2014, № 5, c. 345, 346.

9 О. Токарчук, Бігуни, цит. праця, с. 99.

10 M. Shulgun, The Artistic Objective and Genre Originality in Vasil Golovanov's Travelogue «Gyarb, The Wind From The East», "IntellectualArchive" 2016, vol. 5, № 1, c. 84 
невища, де немає центру, периферії і він є потенційно нескінченним ${ }^{11}$. Авторка заглиблюється у власну екзистенцію і фокусує увагу на психологічних особливостях та не шукає доцентрової точки руху тіла і душі.

Під час подорожі вона помічає людей, спостерігає за ними. Через обопільні записи на папері героїв один про одного, без особистого знайомства, часто без ідентифікації, без ототожнення з земляками, дистанційно комунікує з ними, розчиняючись у такий спосіб у просторі. Це свідчить про зміну парадигми: між людьми сучасної цивілізації відбувається штучне спілкування, утверджується новий спосіб комунікації - спостереження один за одним і записування думок інших. Звідси виокремлюється психологічний портрет нового типу героя - анонімний, не ідентифікований.

У Бігунах значна кількість персонажів не індивідуалізовані. Вони не мають імен. Це герої різних національностей. Тут є: поляки, євреї, росіяни, серби, китайці, просто мандрівники, обходисвіти 3 наплічниками, одні й ті ж самі постійні мандрівники, мусульмани, християни, емігранти, “чоловік, що розводив ослів”, “один чоловік із Китаю”, “одна острів'янка", “один чоловік”, паломники, туристи, волоцюги, "він”"2. I хоча досить часто у творах сучасної літератури відбувається осягнення різних типів ідентичностей (самоідентичності (его-ідентичності), соціальної, національної, громадянської, релігійної, гендерної, етнокультурної, аксіологічної тощо), то Ольга Токарчук у власних екзистенційних пошуках шукає відповіді на філософське питання “що є людина, яка виходить за межі своїх можливостей?”. Така “людина, позбавлена центру, є буттям-між: вона не належить, образно кажучи, ні небу, ні землі. Якщо вона є буттям-між, то вона знаходиться в дорозі. (...) Бути в дорозі означає постійно трансцендувати себе, трансцендувати обставини" ${ }^{13}$, тобто бути поза космічними площинами Неба і Землі.

Часто сучасні автори ставлять за мету "змінити уявлення про світ і розширити межі свідомості людей”'14, тому й руйнують стереотипи щодо розуміння історії, мистецтва, релігії, кордону тощо. Реалії польського простору у творі Ольги Токарчук відсутні - авторка порушує глобальні світові, а не власне національні проблеми: співіснування на Землі людей і тварин, проблеми екології, війни, глобалізації ("вже ніколи не буде окремих екосистем. Світ злився в одне суцільне місиво”), релігії (“Справжній Бог - то звіря”). Її зір фіксує дрібниці та деталі: “Світу забагато, краще

\footnotetext{
11 A. Larenta, Labirynt jako przestrzeń mityczna $w$ Biegunach Olgi Tokarczuk..., цит. праця, c. 341,345 .

12 О. Токарчук, Бігуни, цит. праця, с. 123, 174, 270, 335, 406.

13 І. Карівець, Повсякдення: між трансиенденталізмом і дивовижністю, Львів 2012

14 M. Shulgun, The Artistic Objective and Genre... цит. праця, с. 84.
} 
зосередити увагу на подробицях, а не на цілості”. Себе авторка називає приватним розслідувачем “випадків і знаків"15. Героїня-мандрівниця записує дивні звичаї і традиції, яких немає в їі тезаурусі звичних картинок.

Авторка озвучує амбітні плани людей, які ті втілюють у процесі власних мандрів. Одна з героїнь спонукає всіх людей писати і читати книги. Також польська письменниця говорить про моральні ("Поліція не поспішала прибрати місце [замаху], от-от мав приїхати журналіст”) та про історично-релігійні умовності в житті (“лежить те, що зостається від спаленого тіла просвітленої істоти”). Помічає парадокс планетарної свідомості: протягом тисячоліть люди намагалися продовжити життя мертвому людському тілу, а сучасна людина навпаки - свідомо чи несвідомо живе спілкування перетворює на штучне. Як наслідок, світом заволодіває "нова агресивна форма існування"16 - пластикові пакети.

Героїня компонує власну модель світу-знаку (“я знаходила лише знаки”), що складається з минулого, теперішнього, майбутнього, асоціативного (“ми - міста"), інтуїтивного та генетичного шарів (“світ (...) міститься всередині (...) мозку”), видимого й невидимого - ціле $\epsilon$, або його немає. Вона переконана, що істинне буття проявляє себе у деконструкції, порушенні норм, у помилках, які слід розтлумачити, розкодувати значення й повернути “до певних уявлень” свідомості. У цій психології мандрів до джерел відбувається пошук сенсів, індивідуальне сприйняття буття і конструювання дійсності через окремі ідеї людей та несподівані асоціації й символи (“Фотографії (...) фіксують миті, які інакше були би втрачені назавжди”) ${ }^{17}$. Тобто всі ці процеси плинні, тимчасові й недовговічні, однак, складають каркас постійного.

Ольга Токарчук підводить читача до думки, що світ - трансформаційний, гнучкий і створюється уявою та зводиться до системи координат різноманітних ідей про речі, на які можна подивитися з різної перспективи: "секс і релігія. Тіло і Бог. Фізіологія й теологія"18. У цій системі координат перетинаються прямі, що “біжать із нізвідки в нікуди”; це все створює уявлення позірної розмаїтості, адже світ може акумулюватися у єдиній картині Івана Хрестителя, чи скластися з “нерухомих митей” 19 , або зіткатися 3 переплетених приватних історій, чи з незвичної і недоказової логіки інших людей.

Окремі строкаті різночасові і різнопросторові сюжетні лінії твору (про Куніцького, про Ерика, про Шопена, про Йозефіну Золіман тощо)

\footnotetext{
О. Токарчук, Бігуни, цит. праця, с. 301, 68, 172, 333.

О. Токарчук, Бігуни, цит. праця, с. 74, 125, 173, 301, 400.

Там само, с. 13, 16, 52, 347.

Там само, с. 102.

Там само, с. 59, 67, 389, 392.
} 
авторка дробить на дрібніші історії у вигляді хронік, листів, зізнань, спогадів, мемуарів і всі їх переплітає з історіями своїх мандрів. Досліджує психологію подорожі як фізичного так і духовного міжчасового руху зовнішнім і внутрішнім простором різних світів, цивілізацій, континентів, людського організму мертвого і живого. Показує рух тілесний і Божественний. Колекціонує неординарні людські історії, пізнає світ у розрізі, в різних вимірах, і презентує читачеві мережеву модель всесвіту.

Алогічний хаос різноманітних картинок, незвичних асоціацій, обірваних сюжетних ліній, доповнений життєвими історіями людей з їх дивною логікою, - все це створює буття, що складається з різночасся, різнопростору, однак, $є$ незбагненою цілістю, “мандрівною стереометрією”, гіпотетично пов'язаною між собою якоюсь спільністю ідей і знаків - “все є однією величезною головоломкою”, “усе щось значить" 20 . В усьому можна провести паралелі, адже всі субстанції перетинаються уявними лініями: “Ми несвідомо творимо якусь спільноту, сенс існування якої, втім, для нас лишається незбагненним"21.

У світі безліч невидимих зв'язків і відношень (“подібності знаходяться в зовсім несподіваних місцях" ${ }^{22}$ ), які протягом століть людьми повністю не осягнуто. Саме життя - це “лінії, об'єми, площини”, що перетинаються "в межах короткої миті"”23. I як неможливо остаточно пізнати плюралістичний світоустрій, так і неможливо повністю осягнути будову і внутрішні процеси людського організму, нервова система якого нагадує героїні метрополітен. Індивідуальне ставлення до суті життя під час мандрів проявляється і в авторефлексуванні над процесом власної творчості: "У моїх писаннях життя перетворювалося на уривчасті історії, оніричні оповідки, невиразні сюжети, мерехтіло десь далеко, в незвичних зміщених перспективах або поперечних зрізах - так що важко було сказати хоч щось про цілісність" ${ }^{24}$.

Людське існування $є$ часоплинним: воно залежить від епізодів, пауз, часу, простору, місця. Усі ми сусіди по вертикалі чи по горизонталі, хай навіть на долю секунди ${ }^{25}$. Тому граничні й надчуттєві принципи усвідомлення людського життя, а найперше усвідомлення існування власного "Я", й пізнання самого себе, починається з осмислення в пластах різних реальностей дихотомії "рух - безрух". Авторка також відтворює дискретний рух: углиб людського тіла, 3 якого виходить усвідомлення, що “все знання про світ походить із людської голови”; хаотичний; проти

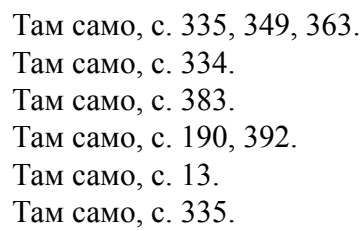


течії; ілюзорний (“ми подорожуємо на місці”); по колу; до Творця ${ }^{26} ;$ рух вільних людей; рух як природна потреба; до власної кінцівки; циклічний; життєворух. Будь-який рух наближає до істини.

Тож, філософія процесу мандрів протягом віків модифікувалася, тому що змінювалася категорія руху, мінялося усвідомлення площин і простору. У XXI столітті мандри можуть перетворюватися на метафору зникнення, чи розчинення: "Плинність, мобільність, ілюзорність - ось що значить бути цивілізованим. Варвари не подорожують, вони просто йдуть до мети або вчиняють наїзди"27. Героїня означує власні мандри як синдром: "Історія моїх мандрів - це лише історія хвороби" 28.

У процесі пізнання і осягнення людина починає писати свою мапу світу й усвідомлювати власне існування за межами себе самої. Мета мандрівника, на думку Ольги Токарчук, - "вистежувати помилки й провали творіння" 29 . Тому героїню твору цікавлять анатомічні театри, у яких можна знайти щось рідкісне, незвичне, неповторне, й оригінальне - людські тіла. Пізнати людський організм означає пізнати світ і себе, тому що, як твердив ще Чарльз Дарвін, історія розвитку людини - це історія розвитку цивілізації. Героїня через анатомічні дані досліджує трансцендентну сутність явищ, намагаючись у такий спосіб зрозуміти причини та засади буття, сприймаючи його як паноптикум - “зіткнення міфу та реальності чіткіше показує трансформації сьогодення" ${ }^{\prime 30}$.

Під час мандрів можна переродитися: “ми, можливо, народимося вдруге - цього разу у правильний час і в правильному місці”, можна втекти у пошуках кращого життя “аби подалі від північного гнилуватого клаустрофобного життя в абсурдній і похмурій комуністичній державі кінця шістдесятих" ${ }^{1}$. Однак мандри можуть і не мати сенсу. Промандрувати безцільно можна все життя. "Чого я шукав?" 32 , - запитує один із героїв. Отож, вихід за межі може мати сенс, а може і не мати.

Метою мандрівника може бути споглядання людини, іiі життя (“Метою паломництва є інший паломник”), чи знаходження відчуття тиші, слухання музики сфер, або пошуки безсмертя, коли "усе здається новим і чистим, цнотливим і в певному сенсі безсмертним"з3. Мета може бути глобальною - пошук істини, досконалості, де "час і місце ідеально співіснують”, а може бути індивідуальною - пошук “власного коріння", знахо-

Там само, с. 73, 136, 148.

Там само, с. 51.

Там само, с. 16.

Там само, с. 17.

S. Iwasiów, ,, Celem mojej pielgrzymki jest zawsze inny pielgrzym ”..., цти. праця, с. 170.

О. Токарчук, Бігуни, цит. праця, с. 389, 408.

Там само, с. 218.

Там само, с. 130, 310, 328. 
дження оригіналу, а не копії, чи щоб “навчитися без кінця вибирати”, або у процесі мандрів "написати велику книгу” про всі злочини “від початку світу”, чи відчути на собі “паризький синдром" 34 . Мета - дискретна.

Мандрівниця веде спостереження над деформаціями категорії часу. Фіксує модуси його тривкості, ущільнення, змінності, наступності, уповільнення, умовності, прискорення. Робить висновки, що кільцевий час існує в осілих народів, а номади використовують лінійний час, який їх наближує до мети. У літаку - час розчинний, у місті - лихоманковий, в пустелі - лінивий ${ }^{35}$. Що час стиснутий - доводить історія про сім років мандрівки, від якої залишилося тільки декілька спогадів ${ }^{36}$. За часом можна гнатися. Він може бути незмінним, чи розтягнутим на десять років. Існують і позачасові місця ${ }^{37}$, де часу не існує. Його може й не бути там, де він повинен бути (“в русі, в подорожі немає часу"38). Він може квапити, і ним можна вимірювати зміни ${ }^{39}$. Також час може стежити за мандрівником, чи навпаки ${ }^{40}$. Він може тривати мить, чи бути стертим: "Час точиться всередині літака, але назовні його нема"41. Час є локальний, і $є$ світовий. Він може бути мертвим і оживленим ${ }^{42}$. Він може служити орієнтиром чи дезорієнтиром, може розростатися, бути вдаваним, чи згущуватися, бути доцентровим чи відцентровим, зовнішнім чи внутрішнім, реальним, чи ірреальним, перекинутим "з ніг на голову" 3 . Він є конкретним і абстрактним, свідомим і несвідомим (“Час і простір ми переживаємо великою мірою несвідомо" ${ }^{44}$ ), художньозримим, суб'єктивним. $€$ час людський і час богів. Отож, час Ольга Токарчук означує не тільки координатами "раніше - пізніше", він $є$ власне створений. Так само сучасна людина сприймає простір і місце. Тобто ці категорії стають особисто іï, а не просто можливі. Людина розчиняється в місцях: у святих місцях - набирається святості, у злиденних - злиднів. Тому у сучасних мандрівників місце ущільнюється (“Мій дім - мій готель"45), або сприймається ним як метафора, чи асоціація.

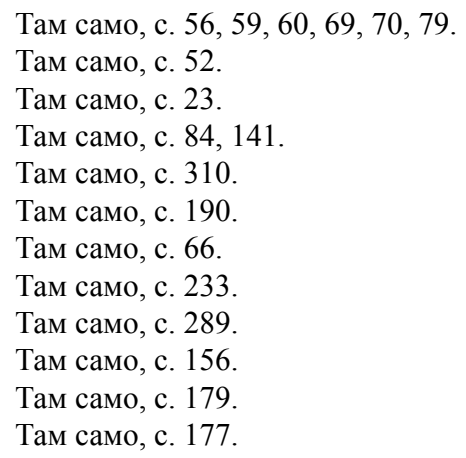


Героїня підсумовує наслідки своїх амбівалентних мандрів: “Я стала зрілішою" - "Я $€$ " розділу Я $\epsilon$ обрамлює твір: повторюється два рази - на початку і майже в кінці. Тож усвідомлення людиною себе самою відбувається відповідно до етапів онтогенезу. Героїня зафіксувала зміни, які з нею відбулися у процесі подорожі і життя, паралельно відзначивши світові зміни.

Письменниця підказує, що для того, щоб зрозуміти світ, потрібно зрозуміти людину. Відділити штучність та ілюзорність від справжнього, від початкового. Звідси виникає прагнення продовжити існування людського тіла полімерною консервацією, зануренням у формалін, пластинуванням, створенням анатомічних воскових фігур тощо. Люди намагаються замінити оригінал на копію, тому й між сучасниками XXI століття відбувається штучне спілкування й подвійне ставлення до одних і тих же речей: десь - вбивають, десь рятують.

Тож, Ольга Токарчук через тканину роману Бігуни вразила читача композицією, сюжетними лініями та філософськими спостереженнями. Під час мандрів, через призму категорій часу, простору та місця, намагалася розібратися в тому, як змінюється сприйняття героями сьогоднішньої реальності. Ї̈̈ висновок - справжність замінюється штучністю, а штучність породжує штучність.

\section{БІБІЛОГРАФІЯ}

Iwasiów Sławomir. 2013. „Celem mojej pielgrzymki jest zawsze inny pielgrzym”: podróż w prozie Olgi Tokarczuk. „Fraza: poezja, proza, esej” r. 22, nr 3 (81): 169-190.

Kalinûško Olesâ. 2014. Žanrovi modifikacï travelogu v romanì Ol'gi Tokarčuk «Bìguni». "Molodij včenij" № 6 (09): 88-92 [Калинюшко Олеся. 2014. Жанрові модифікаuіï травелогу в романі Ольги Токарчук «Бігуни». “Молодий вчений” № 6 (09): 88-92].

Karìvec' İgor. 2012. Povsâkdennâ: miž transcendentalizmom i divovižnìstû. L'vìv: Vidavnictvo L'vìvs'koï politehniki [Карівець Ігор. 2012. Повсякдення: між трансценденталізмом і дивовижністю. Львів: Видавництво Львівської політехніки].

Kozlov Roman. 2012. Hronotopika Frankovih dram: teoriâ, praktika, interpretaciâ. Krivij Rìg: Vidavničij dìm [Козлов Роман. 2012. Хронотопіка Франкових драм: теорія, практика, інтерпретація. Кривий Ріг: Видавничий дім].

Larenta Anna. 2014. Labirynt jako przestrzeń mityczna $w$ Biegunach Olgi Tokarczuk. „Białostockie Studia Literaturoznawcze” nr 5: 341-356.

Shulgun Madlen. 2016. The Artistic Objective and Genre Originality in Vasil Golovanov's Travelogue «Gyarb, TheWindFromTheEast». "IntellectualArchive" vol. 5. № 1: 8292.

Šul'gun Madlena. 2017. Metažanr podorožì v kontekstì perehìdnogo hudožn'ogo mislennâ (kinec' $X X$ - рос̆. XXI st.). Dis. ... dokt. fillol. nauk : 10.01.06; 10.01.05. Кï̈v [Шуль-

46 Там само, с. 399. 
гун Мадлена. 2017. Метажанр подорожі в контексті перехідного художнього мислення (кінець $X X-$ поч. XXI cm.). Дис. ...докт. філол. наук : 10.01.06; 10.01.05. Київ].

Svâto Roksolâna. 2013. Biguni: recenziâ. "Kritika” № 5-6: 187-188 [Свято Роксоляна. 2013. Бігуни: рецензія. “Критика” № 5-6: 187-188].

Tokarčuk Ol'ga. 2011. Bìguni. Pereklad: O. T. Slivins'kij. Harkìv: Folìo [Токарчук Ольга. 2011. Бігуни. Переклад: О. Т. Сливинський. Харків: Фоліо].

\section{SEMANTYKA CZASU I PRZESTRZENI W UTWORZE „BIEGUNI” OLGI TOKARCZUK (ASPEKT PORÓWNAWCZY TRAWELOGU UKRAIŃSKIEGO I POLSKIEGO)}

Streszczenie: W artykule poddano analizie indywidualny model czasoprzestrzennego istnienia, przedstawiony w trawelogu Bieguni współczesnej pisarki polskiej Olgi Tokarczuk, laureatki Nagrody Nobla.

Autor danego tekstu dokonuje analizy porównawczej trawelogu Bieguni i trawelogów współczesnych autorów ukraińskich, wykazuje oczywiste powinowactwa utworów ościennych literatur i wyodrębnia ich cechy wyróżniające.

W artykule podkreśla się, że Olga Tokarczuk rozpatruje filozofię współczesnych wędrówek jako sposób poznania świata przez pryzmat „wyjścia poza granice”, a autorzy ukraińscy podróż prezentują na poziomie przestrzeni wewnętrznej i zewnętrznej. To zestawienie ma za cel pomóc czytelnikom, miłośnikom gatunku trawelogu, bardziej szczegółowo zrozumieć tego typu utwory.

Słowa klucze: trawelog, przestrzeń, czas, miejsce

\section{СЕМАНТИКА ЧАСУ, ПРОСТОРУ, МІСЦЯ Й ГЕРОЯ У ТВОРІ БІГУНИ ОЛЬГИ ТОКАРЧУК}

Резюме: У статті проаналізовано індивідуальну часово-просторову модель буття як сукупність різновидів реальностей художньої дійсності, представлену у творі «Бігуни» сучасною польською письменницею Ольгою Токарчук, лауреаткою Нобелівської премії.

Підкреслено, що Ольга Токарчук філософію мандрів як засобу світопізнання розглядає через призму питання «виходу за межі».

3'ясовано, що герої твору у процесі мандрів певним чином моделюють світ: картину світу наповнюють особистими смислами, залежно від власного світогляду, водночас іметафізичний та географічний простори концептуально переінакшують образ героя. Зміни відбуваються і в реальності: справжність замінюється штучністю, а штучність породжує штучність.

Ольга Токарчук підводить читача до думки, що світ - трансформаційний, гнучкий істворюється уявою та зводиться до системи координат різноманітних ідей. На речі можна подивитися з різної перспективи, а щоб зрозуміти світ, потрібно зрозуміти людину.

Ключові слова: час, простір, місце, герой 